\title{
Fragmenta Excerpti de Thesauri Leguminosarum - Three of the World's First Domesticated Plants in the Indo-European Languages of Europe
}

\begin{abstract}
Aleksandar Mikić
Summary: The words denoting lentil (Lens culinaris Medik.), pea (Pisum sativum L.) and faba bean (Vicia faba L.) in the modern Indo-European languages show a high level of uniformity in morphology and semantics and reveal the traces of mutual borrowings among the languages of different Indo-European branches and the exchanges with the neighbouring non-Indo-European languages. Nearly all modern Indo-European languages derived their words denoting lentil and faba bean from the Proto-Indo-European roots *lent- and *bhabb-, with the same primeval meaning. Among the Proto-Indo-European roots related to pea are *erg $g^{w}[b]-,{ }^{*} g^{\prime} r[a] n$-, *ghArs-, *kek-and * pis-. The collected results offer another testimony how important grain legumes such as lentil, pea or faba bean were in the everyday life of the forefathers of the modern Indo-European nations of Europe and their non-Indo-European neighbours.

Keywords: ethnobotany, etymology, faba bean, grain legumes, Indo-European languages, lentil, lexicology, pea, Proto-Indo-European language
\end{abstract}

\section{Introduction}

Legumes (Fabaceae Lindl., syn. Leguminosae Juss. and Papilionaceae Giseke) are one the richest plant families in the world. They are generally responsible for the regular renewal of soil fertility elsewhere and comprise many economically significant species. Among the traditional cultivated annual legumes of the Old World, becoming later extensively grown in the New World as well, are lentil (Lens culinaris Medik.), pea (Pisum sativum L.) and faba bean (Vicia faba L.). One of the greatest advantages of these three crops is their multi-functionality, meaning that they may be used for both human consumption, in animal feeding and various non-food purposes, such as green forage, forage dry matter, forage meal, silage, haylage, immature pods, immature grains, mature grains, straw and green manure (Mihailović et al. 2010). However, lentil, pea and faba bean are usually and primarily considered as grain legume crops important in human diets and are often designed most precisely as pulses, representing today one of the most valuable sources of plant protein.

Lentil and pea originated in the Near Eastern and Mediterranean centres of diversity, while faba bean originated in the Central Asian centre of

A. Mikić

Institute of Field and Vegetable Crops, Maksima Gorkog 30, 21000 Novi Sad, Serbia

e-mail: aleksandar.mikic@nsseme.com diversity (Zeven \& Zhukovsky 1975). All three species became one of the first domesticated plant species in the world, along with few other grain legumes such as chickpea (Cicer arietinum L.), grass pea (Lathyrus sativus L.) and bitter vetch (Vicia ervilia (L.) Willd.) and several cereals (Zohary \& Hopf 2000). The earliest archaeological evidence on these crops is located in several sites in Syria and belongs to 10th and 9th millennia BC (Tanno \& Willcox 2006). Lentil, pea and faba bean played a prominent role in the 'agricultural revolution' of the post-glacial Europe, quickly reaching its farthest parts (Ljuština \& Mikić 2010). Crossing from Asia Minor to the Balkans, they climbed up the Danube valley, leaving behind the Neolithic tells such as Gomolava in Serbia (Medović \& Mikić 2014) and reaching the area of present Paris (Bakels 1999) and Armenia (Hovsepyan \& Willcox 2007) roughly at the same time, namely in the second half of the 6th millennium BC.

According to the one of the most widely accepted theories, the Proto-Indo-Europeans, the people who spoke the assumed Proto-IndoEuropean language, ended their ethnic development and became distinctive in the Pontic-Caspian steppe during the 5th and 4th millennia BC (Anthony 2007).
Acknowledgements: Project TR-31024 of the Ministry of Education, Science and Technological Development of the Republic of Serbia. 


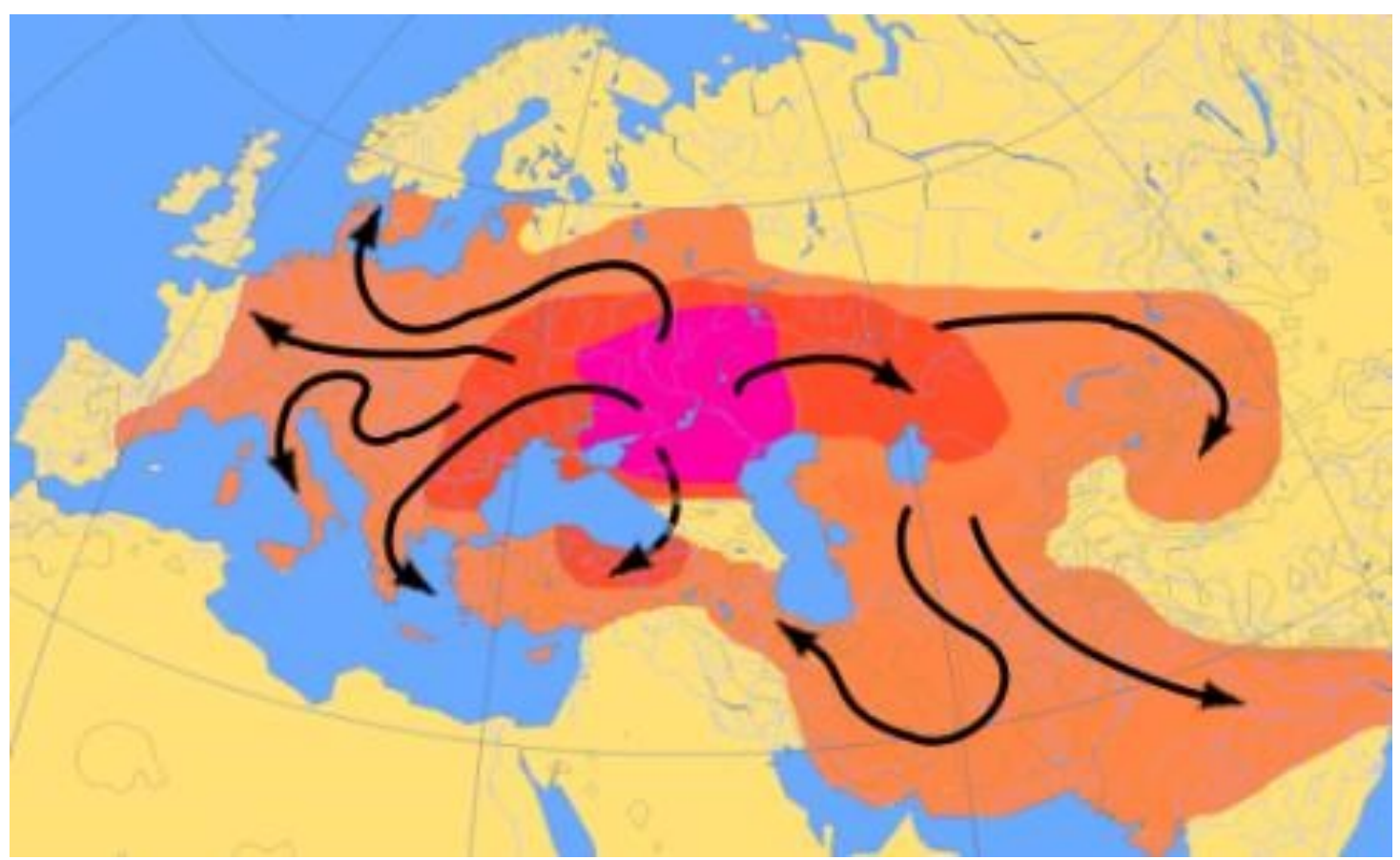

Figure 1. Map of Indo-European migrations from about 4,000 to 1,000 BC; the pink-coloured area corresponds to the assumed Proto-Indo-European homeland, the red-coloured area denotes the area settled up to 2,500 $\mathrm{BCE}$ and the orangecoloured area reached by 1,000 BCE (Beckwith 2009)

Later, they began migrations in almost all directions and produced numerous direct and indirect and extinct and living ethnolinguistic groups, many of which resulted in the majority of modern European nations and their languages and dialects (Beckwith 2009) (Fig. 1). Due to a geographical proximity between the centres of origin of lentil, pea and faba bean and the hypothetical Proto-IndoEuropean homeland, one may be nearly quite convinced that the Proto-Indo-Europeans cultivated these three along with other basic crops (Mikić et al. 2012).

This brief lexicological review aims at emphasizing an outstanding conservativeness of the Proto-Indo-European roots related to these three important grain legume crops, as well as at presenting the immense richness and variability of the words denoting lentil, pea and faba bean in the modern Indo-European languages of Europe.

\section{Materials and Methods}

This preliminary study of the origin and diversity of the words denoting traditional Eurasian grain legumes in the Indo-European languages of Europe has been conducted in two steps:

- The first step aimed to determine the present lexicological diversity, consisting of searching all available printed and electronic dictionaries of the living IndoEuropean languages of Europe and collecting all the words that denote lentil, pea and faba bean;

- In the second stage, the existing etymological dictionaries and other relevant linguistic history resources regarding to Indo-European languages of Europe and its descendants were searched for all the root words related to these three grain legume crops.

These two corpuses were then linked together, attempting to provide linguists and crop historians with attested and assumed forms of the words denoting the targeted grain legumes in Indo-European languages of Europe.

\section{Results}

\section{Lentil}

In general, the words denoting lentil in the modern languages of Europe show even more prominent morphological similarity in comparison to those denoting pea, both within and among individual branches (Table 1). This is specifically evident in Baltic languages, with the Latvian léca, Celtic languages, with the Scottish Gaelic leantail, Germanic languages, with the Danish linse, the Dutch linze and the Swedish lins, and Italic languages, with the Catalan Ilentia, Italian lenticcbia and the Romansh lentiglia. Slavic languages seem to have two distinct forms related to lentil; one present in the Bulgarian leshta, Croatian and Serbian leća and the Rusyn lenća, and another one in the form of the Russian chechevitsa, the Slovak sosovica and the Upper Sorbian sok. The remaining IndoEuropean languages of Europe, such as Greek, with fakí, have a clearly different morphology in comparison to the previous ones, with an exception of the Ossetic qadur that seems to be related to its word denoting pea. 
Table 1. Words denoting lentil in modern Indo-European languages of Europe

\begin{tabular}{|c|c|c|c|c|c|}
\hline Branch & Language & Word & Branch & Language & Word \\
\hline \multicolumn{2}{|l|}{ Albanian } & thjerrëz & \multirow{9}{*}{ Italic } & Galician & lentella \\
\hline \multicolumn{2}{|l|}{ Armenian } & $o s p$ & & Italian & lenticchia \\
\hline \multirow{2}{*}{ Baltic } & Latvian & lèca & & Occitan & mendilh \\
\hline & Lithuanian & lešis & & Portuguese & lentilha \\
\hline \multirow{5}{*}{ Celtic } & Breton & pizenn rous & & Romanian & linte \\
\hline & Irish & lintile & & Romansh & lentiglia \\
\hline & Manx & pishyr lughag & & Sardinian & lentígia \\
\hline & Scottish Gaelic & leantail & & Spanish & lenteja \\
\hline & Welsh & corbysen & & Walloon & lintile \\
\hline \multirow{8}{*}{ Germanic } & Danish & linse & \multirow{14}{*}{ Slavic } & Belarusian & sačavica \\
\hline & Dutch & linze & & Bulgarian & leshta \\
\hline & English & lentil & & Croatian & léca \\
\hline & Flemish & lins & & Czech & čockea \\
\hline & German & Linse & & Lower Sorbian & sok \\
\hline & Icelandic & linsa & & Macedonian & lekja \\
\hline & Norwegian & linse & & Polish & soczentica \\
\hline & Swedish & lins & & Russian & chechevitsa \\
\hline \multicolumn{2}{|l|}{ Greek } & faki & & Rusyn & lenča \\
\hline \multirow{2}{*}{ Indo-Iranian } & Kurdish & nîsk & & Serbian & sočivo; lecia \\
\hline & Ossetic & qadur & & Slovak & sosorovica \\
\hline \multirow{3}{*}{ Italic } & Catalan & Ilentia & & Slovenian & leča \\
\hline & Corsican & lentichja & & Ukrainian & sochevitsia \\
\hline & French & lentille & & Upper Sorbian & sok \\
\hline
\end{tabular}

Table 2. Words denoting pea in modern Indo-European languages of Europe

\begin{tabular}{|c|c|c|c|c|c|}
\hline Branch & Language & Word & Branch & Language & Word \\
\hline \multicolumn{2}{|l|}{ Albanian } & bizele & \multirow{11}{*}{ Italic } & Catalan & pèsol \\
\hline \multicolumn{2}{|l|}{ Armenian } & olor & & Corsican & pisu \\
\hline \multirow{2}{*}{ Baltic } & Latvian & zirni & & French & pois \\
\hline & Lithuanian & žirnis & & Galician & ervella \\
\hline \multirow{6}{*}{ Celtic } & Breton & piz. & & Italian & pisello \\
\hline & Cornish & pýsen & & Occitan & pòis \\
\hline & Irish & pis & & Portuguese & ervilha \\
\hline & Manx & pishyr & & Romanian & mazăre \\
\hline & Scottish Gaelic & peasair & & Sardinian & pisu \\
\hline & Welsh & pysen & & Spanish & guisante \\
\hline \multirow{11}{*}{ Germanic } & Danish & art & & Walloon & $p e \hat{u}$ \\
\hline & Dutch & erwt & \multirow{15}{*}{ Slavic } & Belarusian & garoh \\
\hline & English & pea & & Bulgarian & grah \\
\hline & Faroese & ertur & & Croatian & grašak \\
\hline & Flemish & erwt & & Czech & brách \\
\hline & Frisian & eart & & Kashubian & groch \\
\hline & German & Erbse & & Lower Sorbian & groch \\
\hline & Icelandic & erta & & Macedonian & grašok \\
\hline & Norwegian & ert & & Polish & groch \\
\hline & Swedish & $\ddot{a r t}$ & & Russian & gorokh \\
\hline & Yiddish & arbes & & Rusyn & brašcok \\
\hline \multicolumn{2}{|l|}{ Greek } & bizéli & & Serbian & grašak \\
\hline \multirow{3}{*}{ Indo-Iranian } & Kurdish & polik & & Slovak & brach \\
\hline & Ossetic & tymbylqadur & & Slovenian & grah \\
\hline & Romani & boobi & & Ukrainian & gorokh \\
\hline Italic & Aromanian & gräshac & & Upper Sorbian & broch \\
\hline
\end{tabular}


Pea

The collected words related to pea in the modern Indo-European languages of Europe generally show a considerable morphological uniformity within individual branches (Table 2). Good examples are Baltic languages, Germanic languages, with the German Erbse, the Icelandic erta and the Yiddish arbes, as well as Slavic languages, with the Belarusian garoh, the Kashubian groch and Lower Sorbian groch. The words denoting pea in all six surviving Celtic languages, such as the Cornish pyisen, are morphologically close to the majority of the modern Italic, that is, Romance languages, with the Corsican pisu, the French pois and the Walloon peû. Similarities to these are also present in Albanian, with bizele, Greek, with bizéli and English, with pea. On the other hand, a considerable number of the Romance languages is characterised with different forms of the words related to pea, such as the Galician ervilha, the Romanian mazăre or the Spanish guisante. The Armenian language and the representatives of the
Indo-Iranian branch in Europe have morphologically distinct forms of the words denoting pea, such as the Armenian olor and the Kurdish polik.

\section{Faba bean}

Rather similarly to the words denoting lentil, the words related to faba bean in the modern IndoEuropean languages of Europe (Table 3) demonstrate a considerable morphological inter- and intra-branch uniformity, as witnessed by Baltic, with the Lithuanian pupa, Germanic, with the Faroese bona, the Frisian beanne and the Norwegian bonne, Italic, with the Aragonese faba, the Friulian fave and the Occitan fava, and Slavic branch, with the Czech bob, the Polish bób and the Ukrainian bib. The Celtic languages seem morphologically close to both Germanic, as seen in the Irish pónaire, and Italic languages, supported by the Welsh ffa. Some words related to pea in certain languages are morphologically similar to those belonging to another branch, such as the Romani boba with the Slavic ones.

Table 3. The words denoting faba bean in modern Indo-European languages of Europe

\begin{tabular}{|c|c|c|c|c|c|}
\hline Branch & Language & Word & Branch & Language & Word \\
\hline \multicolumn{2}{|l|}{ Albanian } & bathë & \multirow{11}{*}{ Italic } & Friulian & fave \\
\hline \multicolumn{2}{|l|}{ Armenian } & lobi & & Galician & $f a b a$ \\
\hline \multirow{2}{*}{ Baltic } & Latvian & pupas & & Italian & fava \\
\hline & Lithuanian & pира & & Ladino & ava \\
\hline \multirow{6}{*}{ Celtic } & Breton & fav & & Occitan & fava \\
\hline & Cornish & fav & & Picard & fêfe \\
\hline & Irish & pónaire & & Portuguese & fava \\
\hline & Manx & poanrey & & Romanian & $b o b$ \\
\hline & Scottish Gaelic & pònair & & Sardinian & $f a$ \\
\hline & Welsh & $f f a$ & & Spanish & baba \\
\hline \multirow{9}{*}{ Germanic } & Danish & bonne & & Walloon & féve \\
\hline & Dutch & boon & \multirow{14}{*}{ Slavic } & Belarusian & bob \\
\hline & English & bean & & Bulgarian & bob \\
\hline & Faroese & bona & & Croatian & bob \\
\hline & Frisian & beanne & & Czech & bob \\
\hline & German & Bobne & & Kashubian & bób \\
\hline & Icelandic & baun & & Lower Sorbian & bob \\
\hline & Norwegian & bonne & & Macedonian & bob \\
\hline & Swedish & böna & & Polish & bób \\
\hline Hellenic & Greek & koukiá & & Russian & bob \\
\hline \multirow{2}{*}{ Indo-Iranian } & Ossetic & qadur & & Rusyn & bob \\
\hline & Romani & boba & & Serbian & $b o b$ \\
\hline \multirow{3}{*}{ Italic } & Aragonese & $f a b a$ & & Slovak & bob \\
\hline & Catalan & fava & & Slovenian & bob \\
\hline & Corsican & fava & & Ukrainian & $b i b$ \\
\hline
\end{tabular}




\section{Discussion}

The most recent anthropological analyses of human ancient DNA (aDNA) support the hypothesis of the Proto-Indo-European homeland in the PonticCaspian steppe. The Proto-Indo-European society may be identified with the Yamnaya culture, which subsequently gave origin to the Corded Ware culture, established by a large part of the Indo-Europeanspeaking migrating herders westwards (Balter \& Gibbons 2015). There, in a vast region from Jutland and South Scandinavia to Dnieper, this culture brought forth the Proto-Balto-Slavic and Proto-Germanic societies that in turn proved to be 'green-fingered' growers of grain legumes (Mikić 2015).

\section{Lentil}

The words denoting lentil in majority of the modern Indo-European languages of Europe (Table 1) demonstrate a high level of mutual similarity due to the common origin, the Proto-Indo-European root *lent-, with the same unchanged meaning throughout millennia of separate evolutions of each of its descendants (Pokorny 1959, Nikolaev 2007). Among its direct derivatives, progenitors of the modern individual branches of the Indo-European language tree, are Proto-Baltic *leñs-ia-, Proto-Germanic *lins-ì(n-), Latin lèns and Proto-Slavic *letjā (Vasmer 1955) (Fig. 2).

It is curious that the Slavic languages have another word denoting pea, in some, such as Serbian (Table 1), used in parallel with the one derived from the first root. Such words were derived from the Proto-Slavic * sočevica (Vasmer 1958), with the same meaning and in perhaps in some, so far unexplained, connection to the ProtoSlavic $*_{s o k} \breve{u}$ and the Proto-Indo-European $*_{s}(w) o k w^{w}$, both meaning juice (Mikić-Vragolić et al. 2007).

Like the Kurdish nisk, the Armenian osp remains of uncertain origin, but shares its morphology with the neighbouring Kartvelian language, Georgian, with osp'i (Mikić 2010). In some Celtic languages, such as Breton or Manx (Table 1), the words denoting lentil are actually based upon the words denoting pea with added prefixes. Similarly to its word for pea, the Ossetic qadur is a borrowing from the Caucasian languages.

Pea

There are several Proto-Indo-European roots that initially were or later became associated with pea (Mikić 2009).

The words denoting pea in modern Baltic languages (Table 2) owe their origin to the Proto-Baltic * irirn-ia-, *airn-i $\tilde{\bar{a}}$, denoting both corn and pea, and ultimately to the Proto-Indo-European * ${ }^{\prime}$ er $[a] n$-, * grän-, also denoting grain and corn (Pokorny 1959, Nikolaev 2007). From the Old Baltic tribes, this word was borrowed by their Uralic-speaking neighbours, as witnessed by the Modern Estonian hernes or Modern Finnish herne (Stoddard et al. 2009).

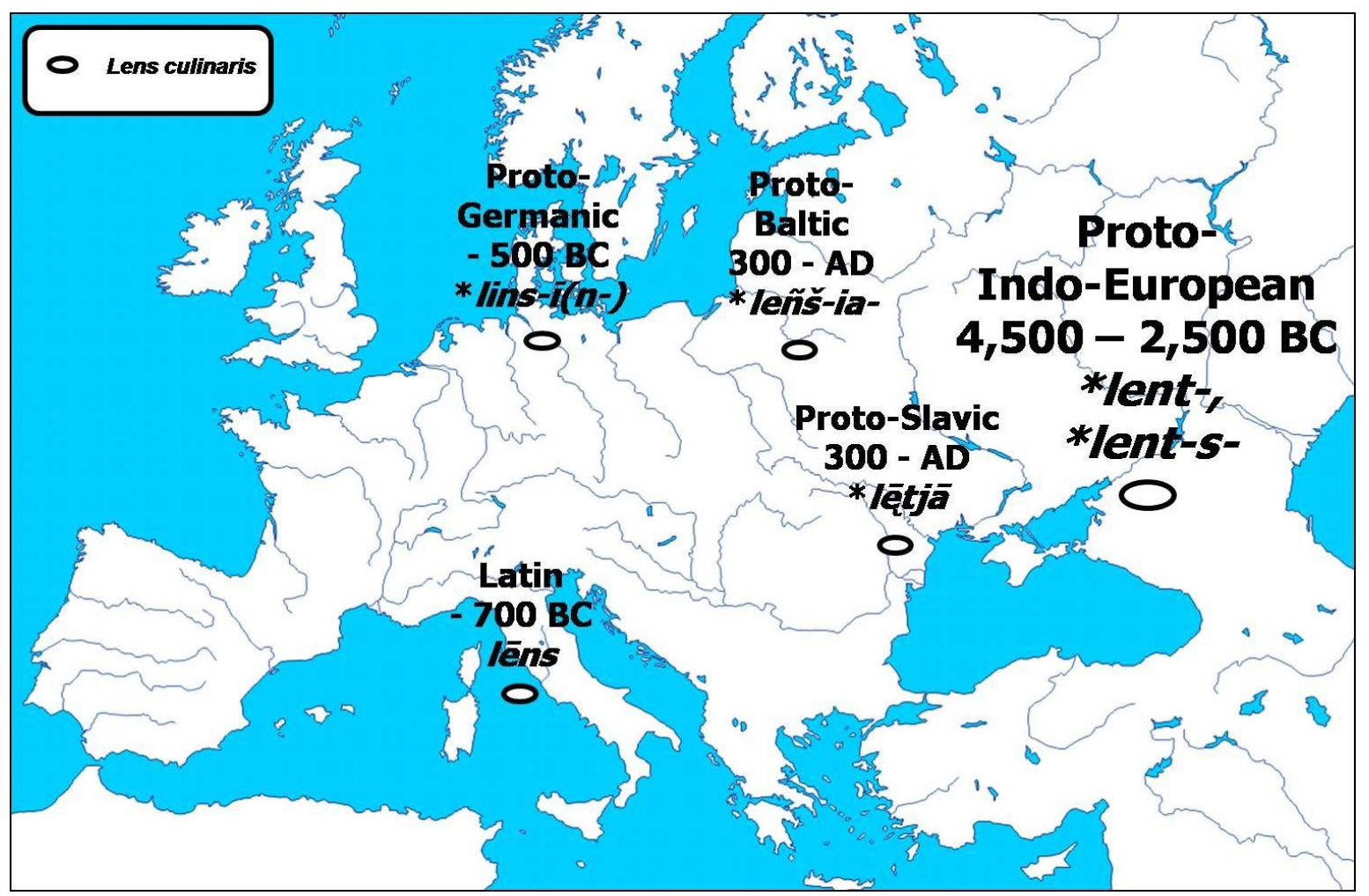

Figure 2. Evolution of the Proto-Indo-European root *lent- 


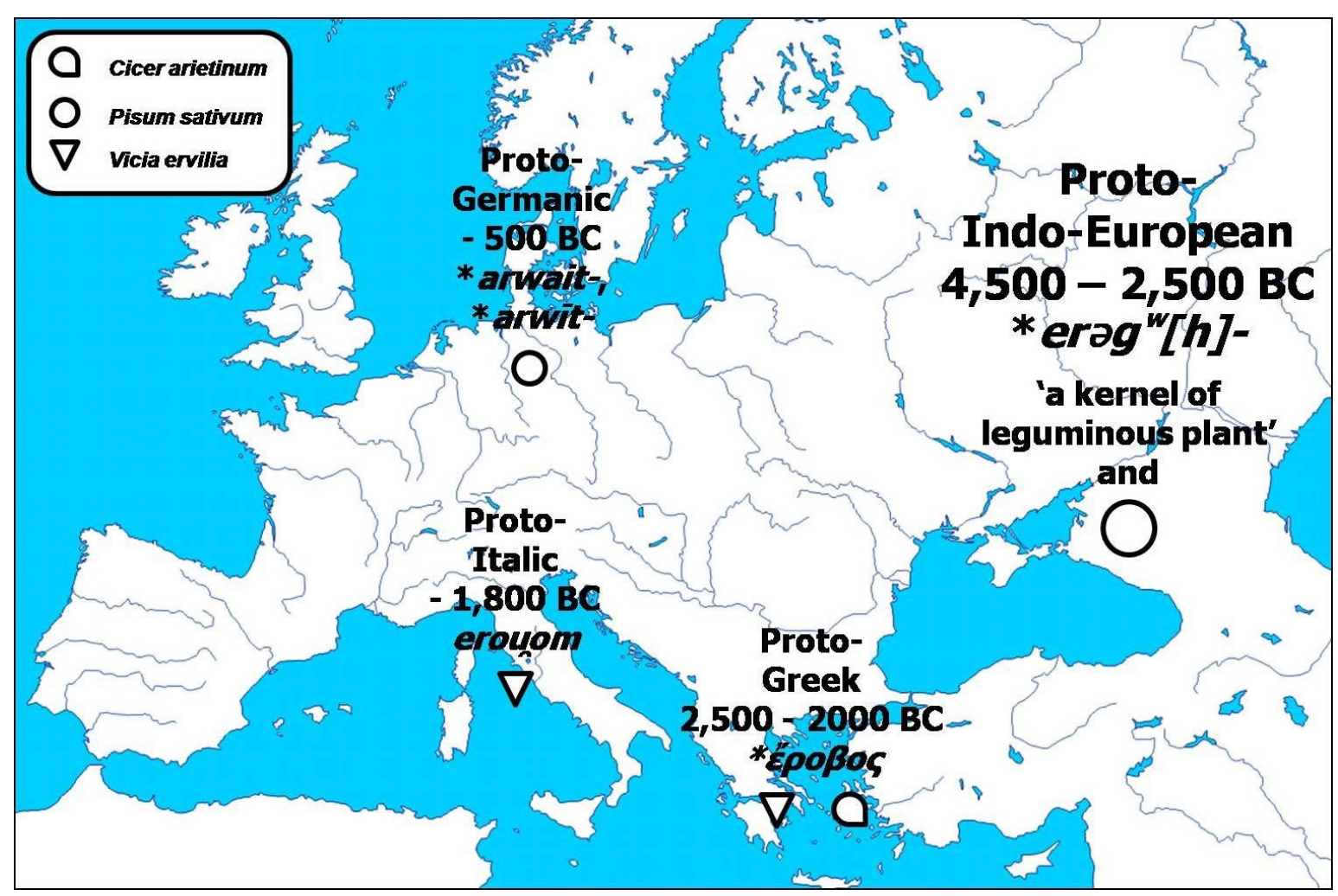

Figure 3. Evolution of the Proto-Indo-European root $*_{\text {erag }}{ }^{w}[h]$ -

Many were the descendants of the Proto-Indo-

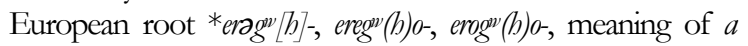
kernel of leguminous plant and pea (Pokorny 1959, Nikolaev 2007) (Fig. 3). One of them was the Proto-Germanic root $*$ arwait $=$, ${ }^{\text {arwit }}=$, denoting pea and having a rich evolution that produced the words for pea in nearly all modern Germanic languages (Table 2). The traces of the words denoting pea in the extinct Germanic languages, especially in those spoken by the tribes that invaded and destroyed the West Roman Empire, still can be found in the local languages and dialects of Italy, such as Bolognese with arvajja or West Lombard with erbion, and Spain, with arbeyu in both Asturian and Leonese. In Modern Spanish, the original Germanic words also exist in the form of arveja, as one of the words denoting pea, and alverjón, arvejo or arvejote, all denoting grass pea. It is noteworthy that the said original Proto-IndoEuropean root also gave Latin ervum, with a meaning shifted from original pea to bitter vetch, but shifted back to pea in Modern Galician and Modern Portuguese.

A consistent uniformity of the words denoting pea in modern Slavic languages is a consequence of a rather good preservation of the Proto-Slavic word for this species, *gorbu (Vasmer 1953). This root, in its turn, was derived from the Proto-Indo-European $*_{g h}$ Ars-, ghers-2, denoting a leguminous plant in general (Pokorny 1959, Nikolaev 2007). These Slavic forms were borrowed by the neighbouring languages such as Albanian, as gróshë and denoting common bean (Phaseolus vulgaris L.), and Aromanian, as grãshac and with the retained original meaning.

The only attested Proto-Indo-European root denoting pea is *keke-, *k'ik'-, kîkêr-, that changed its original meaning in all its descendants, in which it started to denote chickpea, except Old Prussian, an extinct Baltic language, where it was preserved (Nikolaev 2007) (Fig. 4).

The Proto-Indo-European root*pis-, meaning to pound, to thresh (Pokorny 1959, Nikolaev, 2007) is an ultimate source of the words denoting pea in majority of the modern Italic, that is, Romance languages (Table 1). This root evolved into the Latin verb pinsō, -ere, with the same meaning, that, in its turn, gave the well-known pisum (Mikić et al. 2012). This is a fine example of how the words denoting an action, in this case threshing the pea seeds from pods, finally becomes the word that denote the species (Mikić and Stoddard 2009). The Latin pisum was borrowed into other Indo-European, such as Albanian, all modern Brythonic and Goidelic Celtic languages (Macbain 1911), English and Greek, as well as non -Indo-European languages, such as the neighbouring Altaic language, Turkish, in the form of bezelye (Nişanyan 2002).

The word denoting pea in Armenian, olor, is of uncertain origin. The Kurdish polik could be a borrowing from the Semitic languages, namely Arabic, with fül-, or Hebrew, with pöl (Militarev 2006). The Ossetic tymbylqaedur was borrowed from the neighbouring Caucasian languages, where the Proto -Caucasian root * qör'à denotes pea (Nikolayev \& Starostin 1994). The Romanian mazăre is of pre-Roman, Dacian, origin and is related to the Albanian modhë, its alternative word denoting pea. The most widely used word denoting pea in Spanish, guisante, has a common origin with the French gousse, denoting pod, in the Latin vulva, meaning envelope (Mikić et al. 2012). 


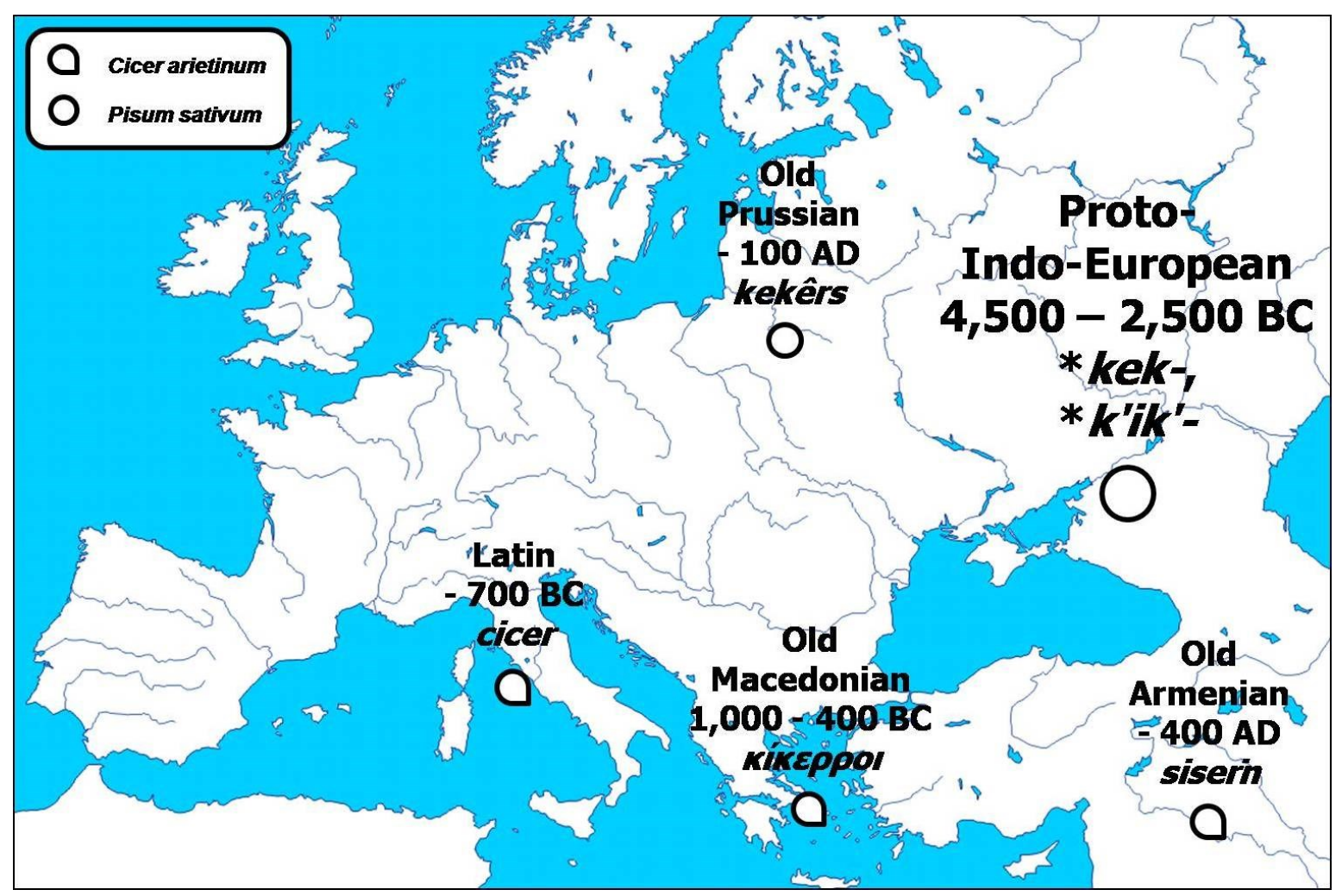

Figure 4. Evolution of the Proto-Indo-European root *kek-

\section{Faba bean}

Similarly to lentil, the words related to faba bean in the modern Indo-European languages and reveal another example of a remarkable degree of mutual similarity. It is commonly regarded that the ProtoIndo-European root denoting faba bean was *bhabh-, bhabha $\bar{a}$, meaning literally something swelling (Pokorny 1959, Nikolaev 2007). Among its close descendants are 1) the supposed Proto-Albanian root *bhakea, giving the form in Modern Albanian, 2) the Old Prussian baba and babo, 3) the Proto-Germanic *bau-no $(n-)$, responsible for the words all modern Germanic and all modern Goidelic Celtic languages (Macbain 1911), 4) baba in the extinct Faliscan and faba in Latin, with the latter being ultimate source of the words all modern Italic and all three surviving Brythonic Celtic languages, and 5) the Proto-Slavic *bobü, retaining almost unchanged in all its living descendants (Vasmer 1953) and being imported into Romanian as bob and Romani as boba. Old Greek is the only language where the original Proto-Indo-European meaning was changed and, in the form of paxos, shifted to denote lentil (Mikić 2011).

Together with the Georgian lobio, the Armenian word lobi could be a borrowing of the Old Greek lobó$s$, denoting a pod of leguminous plants and with an ultimate origin in the Proto-Indo-European root*leb-, denoting blade (Nikolaev 2007).

\section{Conclusions}

In most cases, the words denoting lentil, pea and faba bean demonstrate a considerable uniformity in morphology, especially within individual branches of the Indo-European language family. They also reveal the traces of mutual exchanges among the languages of different Indo-European branches, as well as between them on one side and those of the non-Indo -European families on another side.

Despite a rather preliminary character of the this lexicological research and its incompleteness, the collected results may provide to an equal extent contemporary plant scientists, archaeobotanists and linguists with more testimonies how important grain legumes such as pea, lentil or faba bean must have always been in the everyday life of the forefathers of the modern Indo-European nations of Europe and their non-Indo-European neighbours, as well as to conceive another interdisciplinary collaboration between natural and social sciences.

In memory of Milica Rakić (1996-1999). 


\section{References}

Anthony, D.W. (2007). The Horse, the Wheel, and Language: How Bronze-Age Riders from the Eurasian Steppes Shaped the Modern World. Princeton University Press, New Jersey.

Bakels, C. (1999). Archaeobotanical investigations in the Aisne valley, northern France, from the Neolithic up to the early Middle Ages. Veg Hist Archaeobot 8: 71-77.

Balter, M., \& Gibbons, A. (2015). Indo-European languages tied to herders. Science 347: 814-815.

Beckwith, C.I. (2009). Empires of the Silk Road: A History of Central Eurasia from the Bronze Age to the Present. Princeton University Press, Princeton.

Ljuština, M., \& Mikić, A. (2010). A brief review on the early distribution of pea (Pisum sativum L.) in Europe. Ratar Povrt 47: 457-460.

Macbain, A. (1911). Etymological Dictionary of the Gaelic Language. Eneas Mackay, Inverness

Medović, A., \& Mikić, A. (2014). Archaeobotanical findings of annual and other legumes in Serbia. Legum Perspect 5: 5-6.

Mihailović, V., Mikić, A., Vasić, M., Ćupina, B., Đurić, B., Duc, G., Stoddard, F.L., \& Hauptvogel, P. (2010). Neglected legume crops of Serbia - Faba bean (Vicia faba). Ratar Porrt 47: 27-32.

Mikić, A. (2009). Words denoting pea (Pisum sativum) in European languages. Pisum Genet 41: 29-33.

Mikić, A. (2010). Words denoting lentil (Lens culinaris) in European languages. I Lentil Res 4: 15-19.

Mikić, A. (2011). Words denoting faba bean (Vicia faba) in European languages. Ratar Pourt 48: 233-238.

Mikić, A. (2012). Origin of the words denoting some of the most ancient Old World pulse crops and their diversity in modern European languages. PLoS ONE 7: e44512.

Mikić, A. (2015). Indo-European languages might also be tied to farmers. Science 347: 814-815. http://comments.sciencemag.org/ content/10.1126/science.347.6224.814
Mikić, A., \& Stoddard, F.L. (2009). Legumes in the work of J. R. R. Tolkien. Grain Legum 51: 34

Mikić-Vragolić, M., Mikić, A., Ćupina, B., Mihailović, V., Vasiljević, S., Krstić, Đ., \& Vasić, M. (2007). Words related to some annual legumes in Slavic and other Indo-European languages. Zbornike radova Instituta za ratarstvo i pourtarstvo Novi Sad 44(2): 91-96.

Militarev, A. (2006). Semitic Etymology. The Tower of Babel, an International Etymological Database Project, http:// starling.rinet.ru

Nikolayev, S.L. (2007). Indo-European Etymology. The Tower of Babel, an International Etymological Database Project, http://starling.rinet.ru

Nikolaev, S.L., \& Starostin, S.A. (1994). A North Caucasian Etymological Dictionary. Asterisk, Moscow.

Nişanyan, S. (2002). Sö̈lerin Soyağaci: Cağdaş Türkçenin Etimolojik Sörlïğ̈̈. Adam yay, Istanbul

Pokorny, J. (1959). Indogermanisches Etymologisches Wörterbuch 1. Francke, Bern

Stoddard, F.L., Hovinen, S., Kontturi, M., Lindström, K., \& Nykänen, A. (2009). Legumes in Finnish agriculture: History, present status and future prospects. Agric Food Sci 18: 191205.

Tanno, K., \& Willcox, G. (2006). The origins of cultivation of Cicer arietinum L. and Vicia faba L.: Early finds from Tell el-Kerkh, north-west Syria, late 10th millennium B.P. Veg Hist Archaeobot 15: 197-204.

Vasmer, M. (1953). Russisches etymologisches Wörterbuch 1 (A-K). Carl Winters Universitätsverlag, Heidelberg

Vasmer, M. (1958). Russisches etymologisches Wörterbuch 3 (Sta-Y). Carl Winters Universitätsverlag, Heidelberg

Zeven, A.C., \& Zhukovsky, P.M. (1975). Dictionary of Cultivated Plants and Their Centres of Diversity. Centre for Agricultural Publishing and Documentation, Wageningen

Zohary, D., \& Hopf, M. (2000). Domestication of Plants in the Old World. Oxford University Press, Oxford

\section{Fragmenta Excerpti de Thesauri Leguminosarum- tri među prvim odomaćenim biljkama na svetu $\mathrm{u}$ indoevropskim jezicima Evrope}

\section{Aleksandar Mikić}

Sažetak: Reči koje označavaju sočivo ili leću (Lens culinaris Medik.), grašak (Pisum sativum L.) i bob (Vicia faba L.) u savremenim indoevropskim jezicima pokazuju visoki stepen morfološke i semantičke jednoobraznosti i otkrivaju tragove međusobnih pozajmica jezika različitih indoevropskih grana i razmene sa susednim neindoevropskim jezicima. Reči koje u skoro svim savremenim indoevropskim jezicima označavaju sočivo i bob potiču od praindoevropskih korenova *lent- i $* b h a b h$-, istog prvobitnog značenja. Među praindoevropskim korenima u vezi sa graškom, nalaze se *erggw $[h]-$, ${ }^{*} g^{\prime} r[a] n$-, ${ }^{*} g h$ Ars-, *kek- i * pis-. Sakupljeni rezultati nude dodatno svedočanstvo značaja koji su zrnene mahunarke poput sočiva, graška i boba imale u svakodnevnom životu praotaca savremenih savremenih indoevropskih naroda Evrope i njihovih neindoevropskih suseda.

Ključne reči: bob, grašak, etimologija, etnobotanika, zrnene mahunarke, indoevropski jezici, leksikologija, praindoevropski jezik, sočivo 